\title{
SINTESIS MEMBRAN KOMPOSIT PVDF-ZEOLIT UNTUK PENGHILANGAN METILEN BIRU
}

\author{
ERVIN TRI SURYANDARI ${ }^{1 *}$ \\ ${ }^{1}$ Jurusan Kimia, Fakultas Sains dan Teknologi, UIN Walisongo, \\ Jl. Prof Hamka Kampus 2 Ngaliyan Semarang \\ *alamat email korespondensi: ervin_ts@walisongo.ac.id
}

\section{Informasi Artikel \\ Riwayat Naskah : Diterima pada 24 November 2019 \\ Diterima setelah direvisi pada 26 Desember 2019 Diterbitkan pada 30 Desember 2019}

Kata Kunci:

Membran;

Komposit; PVDF;

Zeolit; Metilen biru

Keywords:

Composite; PVDF;

Zeolites; Methylene Blue.

\begin{abstract}
Abstrak/Abstract
Metilen biru (MB) merupakan zat warna kation yang sering digunakan dalam industri tekstil, karena harganya yang ekonomis dan mudah diperoleh. Dalam pewarnaan, senyawa ini hanya digunakan sekitar 5\% sedangkan sisanya 95\% akan dibuang sebagai limbah. Keberadaannya di lingkungan menurunkan kualitas air dan kenaikan BOD (Biological Oxygen Demand) sehingga dapat merusak keseimbangan ekosistem lingkungan. Metilen biru tidak termasuk zat warna toksik, tetapi dalam keadaan tertentu dapat menimbulkan beberapa efek yang berbahaya seperti jika tertelan dapat menyebabkan kesulitan bernafas, menimbulkan sensasi terbakar dalam mulut, mual, muntah, dan diare. Jika terpapar dalam jangka waktu yang lama, dapat menimbulkan nyeri di dada dan perut, sakit kepala, keringat berlebihan. Oleh karena itu, dibutuhkan penanganan limbah metilen biru yang tepat. Dalam penelitian ini dilakukan pembuatan membran komposit poliviniliden fluorida (PVDF)-Zeolit. Penambahan zeolit ke dalam membran PVDF diharapkan dapat meningkatkan kemampuan membran. Proses pembuatan membran menggunakan metode inversi fasa. Larutan PVDF 20\% larutan PVDF (b/v) dalam $N, N$-dimetilformamida (DMF) sebagai pelarut dan air suling sebagai non-pelarut. Sedangkan membran komposit PVDFZeolit dibuat dengan menambahka zeolit sebesar $20 \%$ (b/b) ke dalam larutan PVDF. Membran yang diperoleh kemudian dikarakterisasi dengan FTIR, SEM, dan ditentukan nilai permeabilitasnya. Berdasarkan citra SEM, membran PVDF bersifat berpori dan penambahan zeolit ke dalam membran PVDF membuat membran menjadi semakin berpori. Membran komposit PVDF-Zeolit memiliki ketebalan yang lebih tipis daripada membran PVDF biasa sehingga proses pemisahan pada membran komposit bisa terjadi lebih cepat. Proses pemisahan metilen biru menggunakan kedua membran diuji berdasarkan penentuan nilai persen rejeksi pada $\mathrm{pH} 3,4,5$, dan 6 . Hasil menunjukkan kedua membran memiliki nilai persen rejeksi optimum pada $\mathrm{pH} 5$ yaitu sebesar 76,45\% dengan nilai permeabilitas sebesar $8,921 \mathrm{Lm}^{-2} \mathrm{~h}^{-1}$ bar $^{-1}$ pada membran PVDF, dan 82,65\% dengan nilai permeabilitas $19,197 \mathrm{Lm}^{-}$ ${ }^{2} \mathrm{~h}^{-1}$ bar ${ }^{-1}$ pada membran komposit PVDF-Zeolit.
\end{abstract}

Methylene blue $(M B)$ is a cation dyestuff that is often used in the textile industry, because of the price and it's easily obtained. In coloring, this compound used about 5\% while the remaining $95 \%$ will be discarded as waste. Its presence decreases water quality and increases in BOD (Biological Oxygen Demand) so that it can damage the balance of the environmental ecosystem. Methylene blue is not a toxic dye, but it can cause some harmful effects such as if swallowed, out of breath, burning sensation in the mouth, nausea, vomiting and diarrhea. If exposed for a long time, it can cause pain in chest and stomach, headaches, excessive sweating. Therefore proper handling of methylene blue waste is needed. In this research, a polyvinylidene fluoride (PVDF)-Zeolite composite membrane was made. The addition of zeolite to the PVDF membrane is expected to increase the ability of the PVDF membrane. The membrane is made using the phase inversion method. A 20\% PVDF solution $(w / v)$ in $N, N$-dimethylformamide $(D M F)$ as a solvent. The PVDF-Zeolite composite membrane made by adding zeolite by $20 \%(w / w)$ to the PVDF solution. The membrane characterized by FTIR, SEM, and the permeability value is determined. Based on SEM images, the PVDF membrane is porous and the addition of zeolite makes the membrane even more porous. PVDF-Zeolite composite membranes have a thinner thickness than PVDF membranes so that the separation process on the composite membrane can faster. The process of separating methylene blue using the two membranes based on determining the percent rejection at $\mathrm{pH} 3,4,5$, and 6 . The results show that the two membranes have optimum rejection percent at $\mathrm{pH} 5$ that is $76.45 \%$ with a permeability $8.921 \mathrm{Lm}-2 \mathrm{~h}-1 \mathrm{bar}-1$ on the $P V D F$ membrane and $82.65 \%$ with a permeability value of $19.197 \mathrm{Lm}^{-2} \mathrm{~h}^{-1} \mathrm{bar}^{-1}$ on the PVDFZeolite composite membrane. 


\section{PENDAHULUAN}

Pencemaran zat warna dalam perairan dapat menimbulkan masalah bagi lingkungan dan dapat membahayakan kesehatan makhluk hidup. Salah satu zat warna tersebut adalah metilen biru, senyawa ini berupa kristal berwarna hijau gelap, ketika dilarutkan dalam air atau alkohol akan menghasilkan larutan berwarna biru. Zat warna metilen biru merupakan zat warna dasar yang penting dalam proses pewarnaan kulit, kain mori, dan kain katun. Dalam proses pewarnaan banyak senyawa sisa yang dibuang sebagai limbah [1]. Penggunaan metilen biru dapat menimbulkan beberapa efek, seperti iritasi saluran pencernaan jika tertelan, menimbulkan sianosis jika terhirup, jika tidak dilakukan pengolahan [2].

Beberapa metode penghilangan metilen biru dari perairan adalah, metode adsorpsi, membran,elektrokoagulasi. Salah satu metode penanganan limbah yang sering dilakukan adalah membran karena dianggap lebih ekonomis, membran yang dibuat dapat digunakan berulang, memiliki ketahanan mekanik dan kimia yang baik serta lebih ramah lingkungan. Membran dapat dibuat menggunakan polimer poliviniliden fluoride (PVDF) yang telah terbukti bersifat stabil pada suhu tinggi, memiliki ketahanan kimia yang baik dan telah banyak diaplikasikan untuk pengolahan limbah air dan penghilang zat pencemar [3].

Proses pemisahan menggunakan membran, seringkali terhambat oleh ukuran pori yang terlalu kecil sehingga mudah menyebabkan penyumbatan, serta menyebabkan proses pemisahannya berlangsung lama dan membutuhkan tekanan yang tinggi. Oleh karena itu, telah banyak penelitian yang melakukan modifikasi terhadap membran, mulai dari pembuatan membran komposit, pembuatan membran serat nano, penambahan suatu senyawa ataupun partikel tertentu yang dapat memperbesar ukuran pori namun tidak mengganggu selektifitas pada membran [4].

Kinerja membran dilihat dari harga fluks atau permeabilitas membran dimana merupakan jumlah volume permeat yang melewati membran per satuan waktu. Untuk meningkatkan nilai fluks, maka yang bisa dilakukan adalah memperbesar ukuran pori. Dengan ukuran pori yang semakin besar maka jumlah volume permeat yang melewati membran akan semakin meningkat pula [5].

Pengembangan membran dengan penambahan material anorganik sebagai pengisi dapat meningkatkan sifat mekanik membran [6]. Bahan material anorganik yang telah digunakan pada penelitian sebelumnya adalah $\mathrm{TiO}_{2}$ [7], $\mathrm{Mg}(\mathrm{OH})_{2}$ [8], dan $\mathrm{ZnO}$ [9].

Membran PVDF mempunyai keunggulan seperti sifat fisik dan mekanik yang tinggi, bersifat hidrofobik (sudut kontak $>90^{\circ}$ ). Dalam proses pengolahan air limbah sifat hidrofobik ini seringkali menghambat kinerja membrandan bisa menyebabkan penyumbatan (foluling). Untuk mengatasi kelemahan ini maka dalam penelitian ini membran PVDF dimodifikasi dengan penambahan zeolit. Zeolit karena mempunyai sifat kapasitas tukar kation yang tinggi, memiliki luas permukaan yang besar, zeolit juga memiliki pori-pori yang dapat berperan sebagai adsorben logam berat dan zat warna kationik. Sehingga harapannya penambahan zeolit ke dalam membran PVDF dapat meningkatkan kemampuannya.

\section{EKSPERIMEN}

Prosedur penelitian ini terdiri dari beberapa tahap penelitian dimulai dari:

a. Pembuatan membran poliviniliden fluorida (PVDF)

b. Pembuatan membran komposit poliviniliden fluoride (PVDF)-Zeolit

c. Karakterisasi membran

\section{Material}

Poliviniliden Fluoride Ko polimer (PVDF), Zeolit 4A Merck, Dimethyl Acetamide (DMAc, pa Sigma Aldrich), Methylene Blue (pa Sigma Aldrich), Aquademinerale.

\section{Instrumentasi}

Instrumentasi yang digunakan untuk karakterisasi adalah SEM Hitachi, FTIR, dan Alat Uji Tarik merk Favigraf.

\section{Prosedur}

Pada penelitian ini membran PVDF dan membran komposit PVDF-Zeolit disiapkan menggunakan metode inversi fasa.

\section{Sintesis Membran}

Pembuatan membran PVDF dengan konsentrasi larutan dope yang digunakan adalah $20 \%(\mathrm{~b} / \mathrm{v})$ polimer dalam DMAc yang dibuat dengan cara menimbang 2 gram PVDF lalu dilarutkan dengan $10 \mathrm{~mL}$ DMAc [10]. Larutan diaduk selama 24 jam sampai homogen dan terbentuk gel kemudian dicetak di atas plat kaca dan dibiarkan selama 30 menit setelah itu 
dimasukkan ke dalam bak koagulan berisi aqua deminerale. Sedangkan pembuatan membran komposit PVDF-Zeolit disiapkan dengan cara yang sama dan menambahkan Zeolit sebanyak $20 \%$ (b/b).

\section{Karakterisasi Senyawa}

Membran yang telah dicetak kemudian dibentuk seperti lingkaran berdiameter $10 \mathrm{~cm}$ menyesuaikan dengan ukuran reaktor membran. Membran yang dibuat kemudian dikarakterisasi dengan:

a. Sudut kontak

Sudut kontak di ukur secara manual berdasarkan metode DSA (Drop Shape Analysis) dengan mengamati sessile drop menngunakan kamera. Image yang teramati kemudian digunakan sebagai dasar untuk perhitungan [11]

\section{b. FTIR}

Analisis FTIR dilakukan dengan melakukan preparasi sampel, sampel dipotong dengan ukuran $2 \times 4 \mathrm{~cm}$ kemudian dilakukan analisa menggunakan teknik ATR. Gugus fungsi yang menjadi fokus dalam penelitian ini yaitu adanya gugus $\mathrm{O}-\mathrm{H}$ pada kisaran panjang gelombang 2500-3400 dan $1600 \mathrm{~cm}^{-1}$, gugus C-H pada bilangan gelombang $3200-2800 \mathrm{~cm}^{-1}$, dan C-F pada panjang gelombang $1400-1200 \mathrm{~cm}^{-1}$, serta Al-O-Al atau Si-O-Si pada $1090-1040 \mathrm{~cm}^{-1}$ [5].

\section{c. Uji Porositas}

Cara yang dilakukan untuk melakukan uji porositas membran yaitu dengan merendam membran dalam air selama 24 jam pada suhu kamar, kemudian memebran ditimbang. Setelah itu membran dikeringkan dalam oven vakum pada suhu $60^{\circ} \mathrm{C}$ selama 48 jam sampai benarbenar kering dan selanjutnya ditimnang kembali. Adapun besarnya porositas membran dapt dihitung menggunakan persamaan berikut ini:

$$
\% \text { Porositas }=\left(\frac{\text { Wwet }- \text { Wdry }}{\text { Wdry }}\right) \times 100 \%
$$

\section{d. Uji Morfologi}

SEM digunakan untuk menentukan morfologi membran. Sampel membran direndam atau dimasukkan ke dalam nitrogen cair selama beberapa detik hingga sampel mengeras, kemudian dipatahkan menggunakan pinset pada kedua sisinya. Kemudian sampel ditentukan morfologi permukaannya juga morfologi pada penampang lintangnya (cross section), dilanjutklan dengan EDX untuk mengetahui unsur apa saja yang ada di dalam membran. Sedangkan untuk melihat sebaran partikel didalam membran dan mengetahui homogenitas membran dilakukan Mapping EDX.

e. Uji ketahanan mekanik

Uji tarik digunakan untuk menentukan sifat mekanik membran. Preparasi dilakukan dengan mengukur ketebalan membran, kemudian membran dipotong $2 \mathrm{~mm} \times 4 \mathrm{~cm}$. Kemudian kedua ujung sampel membran dijepit dengan alat uji tarik dan ditarik hingga putus menggunakan kecepatan $10 \mathrm{~mm} / \mathrm{menit}$. Data yang diperoleh dari hasil uji tarik ini meliputi stress (tegangan) dan strain (regangan) pada kondisi minimal dan maksimal. Alat yang digunakan untuk uji tarik ini adalah merk Favigraf (di laboratorium testing) Balai Besar Tekstil Bandung.

f. Nilai permeabilitas membran

Permeabilitas membran terhadap air diuji dengan cara meletakkan lembaran membran yang telah dicetak di atas penyokong pada rangkaian sel membran seperti pada Gambar 1.

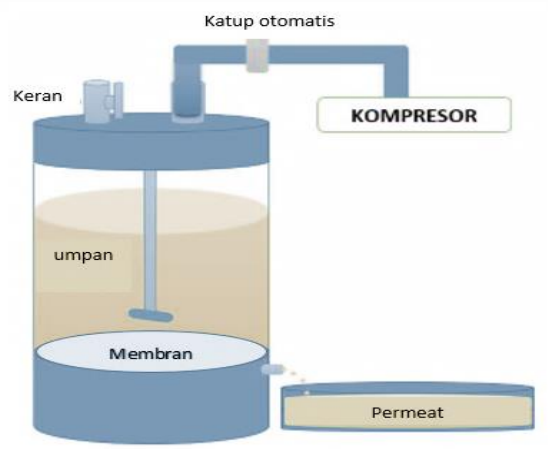

Gambar 1. Skema alat reaktor membran

Kemudian larutan umpan berisi aquademineral dimasukkan ke dalam tangki umpan melalui katup air masuk dan diaduk dengan pengaduk magnetik. Reaktor diberi tekanan sebesar 2 bar dan dibiarkan selama 1 jam sampai terjadi kompaksi. Tekanan pada reaktor yang terisolasi kemudian diturunkan perlahan dengan rentang 0,5 bar. Pada setiap penurunan tekanan dilakukan penampungan permeat dan dihitung waktu tampung menggunakan stopwatch. Nilai fluks kemudian dapat ditentukan berdasarkan Persamaan berikut ini:

$\mathrm{J}_{w}=\frac{\Delta \mathrm{V}}{\mathrm{A} x \mathrm{t}}$

Dengan $\mathbf{J}_{\mathrm{w}}$ adalah fluks $\left(\mathrm{L} / \mathrm{m}^{2} \mathrm{jam}\right), \Delta \mathrm{V}$ adalah volum permeate yang dipindahkan (L), A luas 
permukaan membran efektif $\left(\mathrm{m}^{2}\right)$, dan $\mathrm{t}$ adalah waktu selama penampungan permeat (jam)

\section{g. Penentuan nilai koefisien rejeksi}

Koefisien rejeksi membran terhadap larutan sampel yang sebelumnya telah diatur pHnya menggunakan $\mathrm{pH}$ meter pada $\mathrm{pH} 3,4,5$ dan 6, diuji dengan cara meletakkan lembaran membran yang telah dicetak di atas penyokong pada rangkaian sel membran seperti pada Gambar 1. Kemudian larutan umpan dimasukkan ke dalam tangki umpan melalui katup air masuk dan diaduk dengan pengaduk magnetik. Reaktor diberi tekanan sebesar 2 bar dan dibiarkan selama 1 jam sampai terjadi kompaksi. Tekanan pada reaktor yang terisolasi kemudian diturunkan perlahan dengan rentang 0,5 bar. Pada setiap penurunan tekanan dilakukan penampungan permeat dan dihitung waktu tampung menggunakan stopwatch. Permeat yang ditampung kemudian diukur konsentrasinya menggunakan spektrofotometer UV-Vis. Koefisien rejeksi kemudian ditentukan menggunakan Persamaan berikut:

$\% \mathrm{R}=\frac{\mathrm{C}_{\mathrm{u}}-\mathrm{C}_{\mathrm{p}}}{\mathrm{C}_{\mathrm{u}}} \times 100 \%$

Dengan \% R adalah koefisien rejeksi, $\mathrm{Cu}$ konsentrasi umpan (ppm), dan $\mathrm{Cp}$ konsentrasi permeat $(\mathrm{ppm})$.

\section{HASIL DAN PEMBAHASAN}

\section{Sintesis Membran PVDF}

Dalam melakukan pembuatan membran, pemilihan pelarut serta material akan berpengaruh juga terhadap kerapatan membran yang dihasilkan. DMAc sebagai pelarut dapat menyebabkan pembentukan pori yang besar pada membran sedangkan material berbahan dasar PVDF membran memiliki kerapatan pori yang besar [4], sehingga diharapkan pori yang terbentuk pada membran dari kombinasi PVDF dan DMAc sebagai pelarut tidak terlalu rapat ataupun besar.

Membran yang berhasil dibuat kemudian diukur ketebalannya menggunakan alat mikrometer. Tebal tipisnya ukuran suatu membran dapat berpengaruh terhadap besar kecilnya nilai permeabilitas membran tersebut, karena akan berdampak pada jumlah pori yang terdapat pada membran serta jalur yang dilewati spesi melalui dinding membran. Berdasarkan perbedaan ketebalan membran, semakin tipis membran kemungkinan nilai fluks akan lebih besar dibandingkan membran yang sama dengan ketebalan yang lebih tebal. Artinya proses pemisahan pada membran tipis bisa berlangsung lebih cepat daripada membran tebal. Hal ini tentu saja akan mempengaruhi efisiensi dan kinerja membran. Membran yang baik dan efisien diharapkan memiliki waktu pemisahan yang singkat namun koefisien rejeksi yang tinggi, sehingga dalam penggunaannya tidak membutuhkan tekanan yang terlalu besar serta hemat energi. Membran dengan waktu pemisahan yang lebih cepat dapat menghambat terjadinya fouling sehingga mampu menghemat penggunaan membran dan biaya operasi dari proses pencucian

\section{Karakterisasi Membran}

Karakterisasi membran meliputi sudut kontak, uji tarik, FTIR, uji porositas dan uji SEM

\section{a. Sudut Kontak}

Membran di analisis sifatnya terhadap air melalui sudut kontak. Sudut kontak diukur secara manual dengan metode DSA (Drop Shape Analysis) dengan mengamati sessile drop menggunakan kamera. Dari gambar yang terekam pada kamera kemudian di lakukan perhitungan sudut kontak dengan fiiting menggunakan ImageJ shoftware.

Jika sudut kontak kecil $\left(<90^{\circ}\right)$ menunjukkan tingginya tingkat keterbasahan (membran bersifat hidrofilik), sedangkan sudut kontak yang besar $\left(>90^{\circ}\right)$ menunjukkan tingkat keterbasahan yang rendah (membran bersifat hidrofobik) [12]. Profil tetesan air di atas membran seperti Gambar 2 berikut ini:

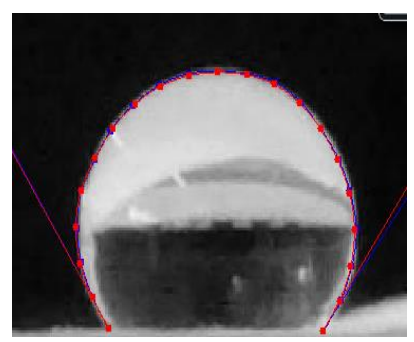

Gambar 2. Gambar profil tetesan untuk sudut kontak pada permukaan membran PVDF.

Dengan menggunakan shoftware ImageJ profil tetesan yang didapatkan dilakukan fitting perhingan sehingga didapatkan harga sudut kontak sesuai dalam Tabel 1 di bawah ini:

Tabel 1. Hasil Uji sudut kontak membran

\begin{tabular}{cc}
\hline Membran & Sudut Kontak $\left(^{(}\right)$ \\
\hline PVDF20\% & 112,40 \\
PVDF-Z1 & 109.42 \\
\hline
\end{tabular}


Tabel di atas juga menunjukkan terjadinya penurunan nilai sudut kontak seiring dengan penambahan komposit yang mengindikasikan terjadinya penurunan tegangan permukaan dan peningkatan energi permukaan, hal ini terjadi karena pengaruh kekasaran permukaan akibat penambahan komposit. b. FTIR

Analisa FTIR terhadap membran PVDF dan membran komposit PVDF-Zeolit bertujuan untuk mengetahui gugus fungsi yang terkandung didalamnya. Spektrum dicatat dari bilangan gelombang $4000-400 \mathrm{~cm}^{-1}$ yang ditunjukkan pada Gambar 3.

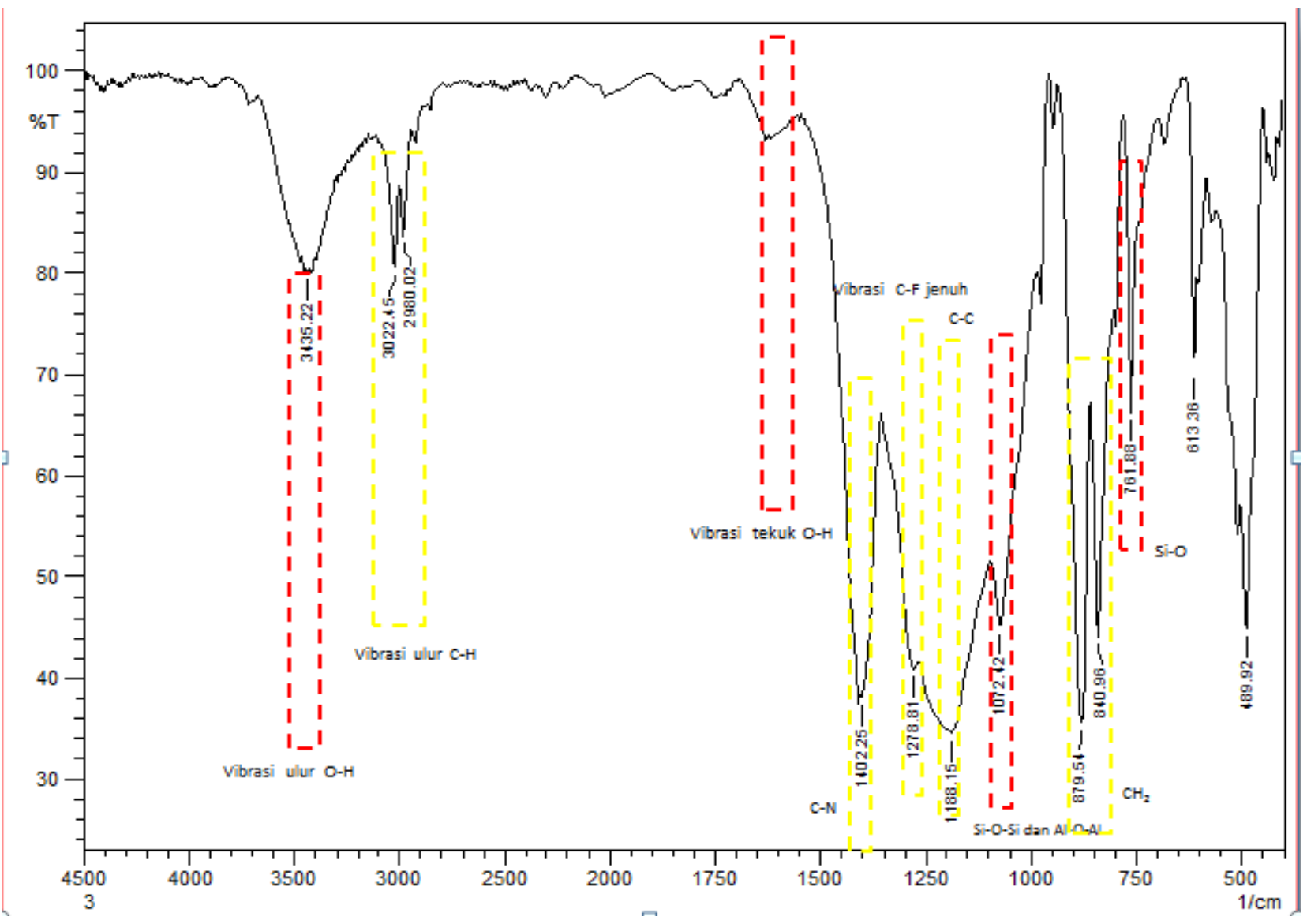

Gambar 3. Spektrum membran komposit PVDF-Zeolit.

Analisis spektrum membran komposit PVDF-Zeolit seperti terlihat dalam Tabel 2 berikut ini:

Tabel 2. Analisis Spektrum membran Komposit PVDFZeolit

\begin{tabular}{cc}
\hline $\begin{array}{c}\text { Bilangan Gelombang } \\
\left(\mathbf{c m}^{-\mathbf{1}}\right)\end{array}$ & Gugus Fungsi Khas \\
\hline $3500-3400$ & Vibrasi ulur O-H \\
$3200-2800$ & Vibrasi ulur C-H \\
1600 & Vibrasi tekuk O-H \\
$1400-1200$ & C-F jenuh \\
$1090-1040$ & Si-O-Si dan Al-O-Al \\
1400 & $\mathrm{C}-\mathrm{N}$ \\
1200 & $\mathrm{CF} 3$ \\
$1100-1200$ & $\mathrm{C}=\mathrm{C}$ \\
800 & $\mathrm{C}-\mathrm{H}$ \\
760 & $\mathrm{Si}-\mathrm{O}$ \\
\hline
\end{tabular}

\section{c. Uji Porositas}

Uji porositas (swelling) dilakukan dengan tujuan untuk mengetahui banyaknya zat yang dapat diserap oleh membran. Pada penelitian ini, uji porositas dilakukan menggunakan air. Besarnya porositas membran dihitung menggunakan rumus 1 dan didapatkan hasil pada Tabel 3 sebagai berikut:

Tabel 3. Harga \% Porositas membran

\begin{tabular}{cc}
\hline Membran & \% Porositas \\
\hline PVDF & 2,4 \\
PVDF-Zeolit & 30 \\
\hline
\end{tabular}

\section{d. Uji Morfologi}

Scanning Electron Microscope (SEM) digunakan untuk melihat morfologi membran PVDF dan sebaran dari partikel-partikel zeolit di dalam membran komposit PVDF-Zeolit. Seperti terlihat dalam Gambar 4 berikut ini: 


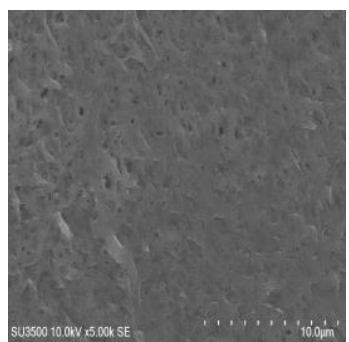

A

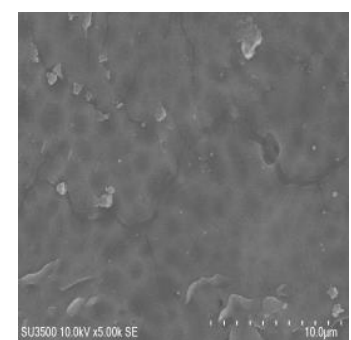

B
Gambar 4. Citra SEM dari membran PVDF (A) dan membran PVDF-Zeolit (B).

Dari gambar di atas, bisa diketahui bahwa dengan penambahan zeolit pada membran PVDF akan memnyebabkan membran menjadi lebih porous, bisa dilihat dalam gambar pori-pori membran lebih banyak dan lebih besar, hal ini sebagai akibat adanya interaksi antara zeolit yang sudah bersifat porous dan polimer sehingga membentuk pori.

Hal ini bisa diperjelas dengan gambar cross section dari membran tersebut dengan berbagai perbesaran yang berbeda, nampak jelas dengan penambahan zeolit pori membran menjadi semakin banyak dan besar seperti Gambar 5.

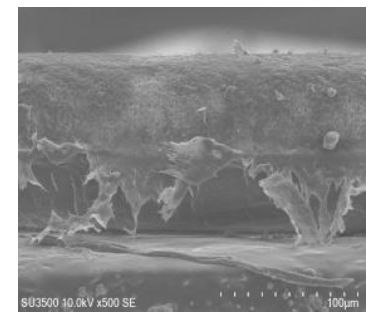

PVDF

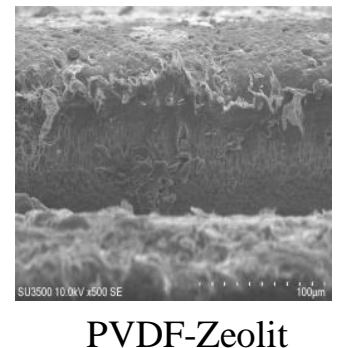

PVDF-Zeolit
Gambar 5. Citra cross section dari membran PVDF dan membran PVDF-Zeolit (500x).

Untuk lebih jelasnya diambil citra SEM untuk mengetahui pori yang terbentuk seperti Gambar 6 berikut ini:

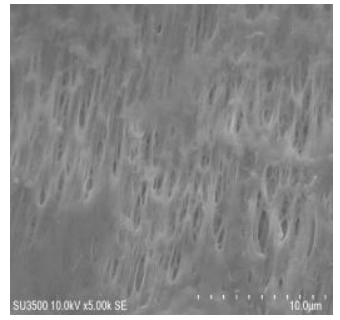

PVDF

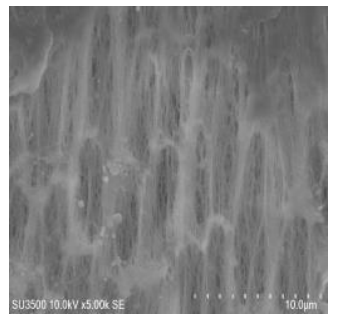

PVDF-Zeolit
Gambar 6. Citra cross section dari membran PVDF dan membran PVDF-Zeolit (5000x).

\section{e. Uji Tarik}

Analisis kekuatan mekanik berdasarkan uji tarik, pengukuran sifat mekanik dilakukan untuk mengetahui kekuatan membran jika dikenai kekuatan yang dapat merusak membran. Sifat mekanik dapat digambarkan melalui pengukuran uji tarik. Uji tarik bertujuan untuk mengukur gaya yang dibutuhkan untuk membuat membran polivinilidene fluoride (PVDF) terputus.

Uji tarik dilakukan pada suhu kamar dengan menggunakan alat Favigraph yang nantinya akan dihasilkan nilai kuat tegang membran pada saat putus dan kekuatan regangan pada saat putus yang dimiliki oleh membran [12]. Tegangan merupakan perbandingan besar gaya terhadap luas bidang penampang. Sedangkan regangan merupakan perbandingan pertambahan panjang membran akibat adanya gaya tarik yang sama besar dan berlawanan arah. Kekuatan mekanik membran dinyatakan dalam modulus young, yaitu perbandingan tegangan terhadap regangan [13].

Data penentuan uji tarik beberapa jenis membran yang telah disintesis dapat dilihat pada Tabel 4.

Tabel 4. Hasil uji tarik pada membran

\begin{tabular}{cccc}
\hline $\begin{array}{c}\text { Jenis } \\
\text { Membran }\end{array}$ & $\begin{array}{c}\text { Regangan } \\
(\mathbf{m m})\end{array}$ & $\begin{array}{c}\text { Tegangan } \\
\text { (MPa) }\end{array}$ & $\begin{array}{c}\text { Modulus } \\
\text { Young }\end{array}$ \\
\hline PVDF20\% & 0,6045 & 12,3134 & 20,3696 \\
$\begin{array}{c}\text { PVDF-Z 2 } \\
(20 \%)\end{array}$ & 0,3086 & 56,2791 & 182,3690 \\
\hline
\end{tabular}

\section{f. Penentuan Nilai Permeabilitas air}

Nilai permeabilitas dapat menunjukkan besarnya efisiensi pemisahan pada membran. Pengukuran permeabilitas dilakukan dengan melakukan pengukuran nilai fluks terlebih dahulu. Pada penelitian ini penentuan nilai fluks dilakukan menggunakan aqua $\mathrm{dm}$ sebagai larutan umpan. Fluks dari masing-masing membran diukur pada tekanan 0,$5 ; 1 ; 1,5$; dan 2 bar. Permeat ditampung pada membran hingga mencapai volum tertentu kemudian diukur waktu yang dibutuhkan selama proses penampungan permeat. Besarnya nilai fluks pada setiap tekanan yang diuji coba, dan dibuat grafik antara fluks vs tekanan. Nilai permeabilitas membran didapatkan dari nilai slope dari persamaan grafik yang diperoleh sesuai Gambar 7 dan 8 berikut ini: 


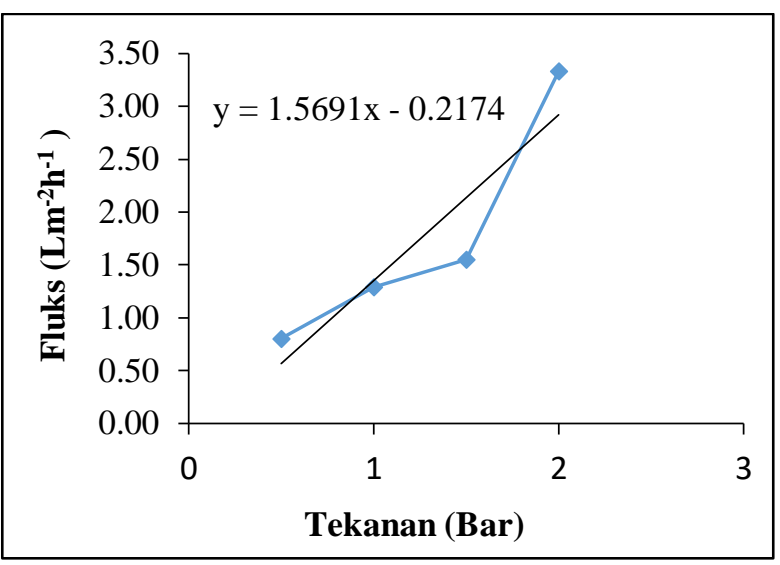

Gambar 7. Grafik perbandingan nilai fluks air terhadap tekanan pada membran PVDF.

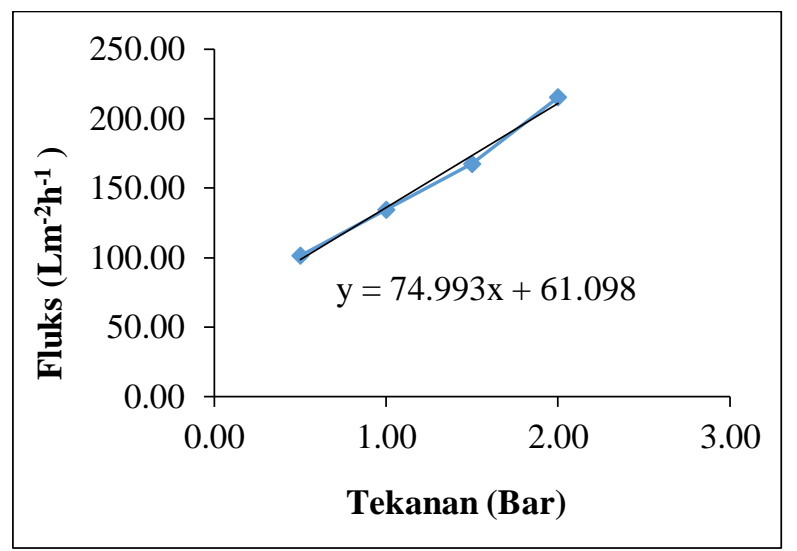

Gambar 8. Grafik perbandingan nilai fluks air terhadap tekanan pada membran komposit PVDF-Zeolit.

\section{g. Penentuan Nilai Permeabilitas Analit}

Sebelum melakukan pengukuran terhadap koefisien rejeksi analit, dilakukan penentuan nilai permeabilitas analit terlebih dahulu. Senyawa methylen biru yang terlarut dalam air akan menyebabkan nilai permeabilitas yang lebih kecil dibandingkan dengan nilai permeabilitas pada air. Hal ini disebabkan oleh ukuran partikel yang terdapat pada larutan lebih besar, sehingga proses yang dilalui umpan ketika menembus membran menjadi lebih panjang. Penurunan nilai fluks dan permeabilitas ini juga dapat disebabkan oleh proses fouling yang disebabkan oleh mengendapnya partikel methylen biru pada permukaan membran akibat perbedaan ukuran antara partikel dan ukuran pori membran. Hasil penentuan nilai permeabilitas analit pada kedua jenis membran dapat dilihat pada Gambar 9 dan 10 berikut ini:

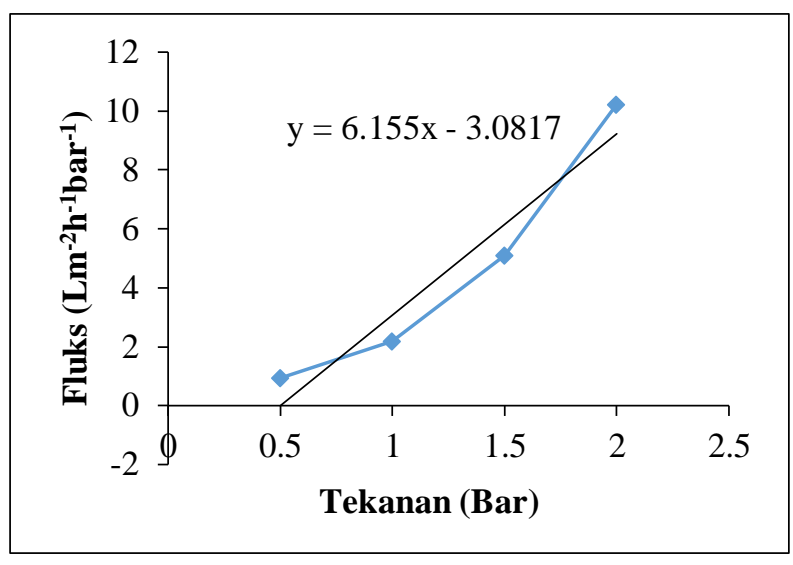

Gambar 9. Grafik perbandingan nilai fluks analit terhadap tekanan pada membran PVDF.

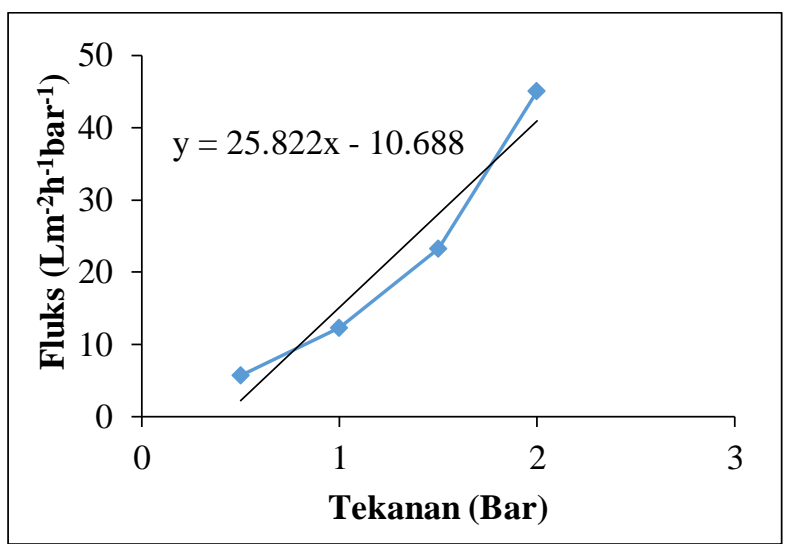

Gambar 10. Grafik perbandingan nilai fluks analit terhadap tekanan pada membran komposit PVDFZeolit.

\section{h. Data persen rejeksi}

Koefisien rejeksi merupakan kemampuan suatu membran dalam menahan suatu spesi dan melewatkan spesi tertentu. Nilai koefisien rejeksi dapat mewakili selektivitas suatu membran. Nilai koefisien rejeksi yang baik akan tercapai jika membran mampu memisahkan hingga mencapai $100 \%$ yang menunjukkan bahwa semua zat terlarut mampu tertahan dengan sempurna oleh membran. Penentuan koefisien rejeksi ditentukan dengan cara melewatkan larutan analit pada membran kemudian dihitung konsentrasi permeat dan umpan untuk mengetahui jumlah analit yang dapat tertahan. Sebagai sampel digunakan larutan metilen biru yang dibuat dan ditentukan konsentrasinya menggunakan spetrofotometer UV-Vis. $\mathrm{pH}$ larutan sampel divariasikan pada $\mathrm{pH} 3,4,5$ dan 6 kemudian diuji menggunakan reaktor membran dengan model dead-end.

Berdasarkan penelitian yang telah dilakukan, kedua jenis membran menunjukkan nilai koefisien rejeksi paling optimum pada $\mathrm{pH} 5$ dan tekanan 1 bar. Hasil penentuan koefisien rejeksi kedua jenis 
membran dapat dilihat pada Gambar 11 berikut ini:

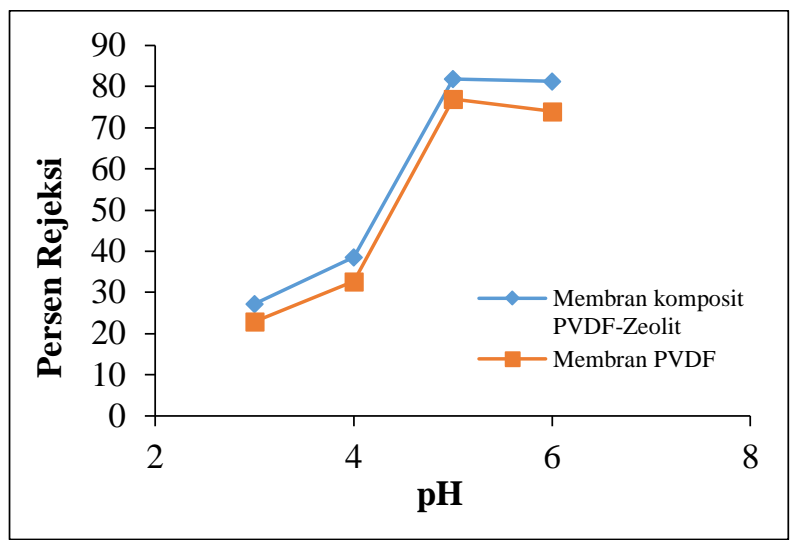

Gambar 11. Grafik perbandingan nilai koefisien rejeksi membran komposit PVDF-Zeolit dan membran PVDF.

\section{SIMPULAN}

Membran PVDF dan membran komposit PVDF-Zeolit sudah berhasil dibuat dengan karakterisasi bersifat porous, bersifat hidrofobik, dan dengan penambahan zeolit ke dalam polimer akan menurunkan sudut kontak dari membran.

Membran komposit PVDF-Zeolit berhasil dibuat dengan ketebalan antara 0,05-0,08 $\mathrm{mm}$ dan ukuran pori rata-rata berada di bawah $2 \mu \mathrm{m}$ sehingga tergolong sebagai membran ultrafiltrasi. Modifikasi membran yang dilakukan dengan penambahan Zeolit sebagai partikel yang terdispersi, dapat meningkatkan nilai permeabilitas dan koefisien rejeksi pada membran. Setelah dilakukan pengujian terhadap kemampuan pemisahan membran komposit PVDF-Zeolit terhadap larutan sampel, maka diketahui koefisien rejeksi membran pada kondisi optimum berada pada tekanan 1 bar dan $\mathrm{pH} 5$ dengan nilai koefisien rejeksi sebesar $82,65 \%$ dan permeabilitas sebesar 19,197 $\mathrm{Lm}^{-2} \mathrm{~h}^{-1}$ bar $^{-1}$. Terjadi kenaikan nilai koefisien rejeksi dan permeabilitas membran yang dimodifikasi dimana pada kondisi yang sama membran PVDF ultrafiltrasi biasa memiliki nilai koefisien rejeksi 76,45\% dan permeabilitas sebesar $8,921 \mathrm{Lm}^{-2} \mathrm{~h}^{-1}$ bar $^{-1}$.

\section{UCAPAN TERIMA KASIH}

Terima kasih kepada UIN Walisongo Semarang yang telah mendanai penelitian ini dengan anggaran DIPA BOPTN 2019.

\section{REFERENSI}

[1] S. T. Riyanto, Degradasi senyawa metilen biru denganmetode elektrolisis menggunakan elektro platinum, Yogyakarta: Prodi Ilmu Kimia, F.MIPA UII, 2009.

[2] G. P. G. P. K. S. V. Gupta, "Removal of Chrome Dyes from aqueous solution by fly ash", Journal of Water, Air and Soil Polluyion, pp. 384-395, 1988.

[3] G. Kang and Y. Cao, "Application and Modification of Polyviniliden Fluorida (PVDF) Membrane", Journals of Membrane Science, vol. 463, no. 1, pp. 145-165, 2014.

[4] R. W. Baker, Membrane Technology and Applications, 3rd penyunt, California: Wiley, 2012.

[5] I. Ike, J. Zhang, A. Groth, J. Orbell and M. Duke, "Effects of dissolution condition on properties of PVDF ultrafiltration membranes", Ultrasonics-Sonochemistry, vol. 39, pp. 716-726, 2017.

[6] J. Li, Y. Hu, L. Zhu, J. Wang and C. Du, "Fabrication and Characterization of a novel $\mathrm{TiO}_{2}$ nanoparticle self-assembly membrane with improved fouling resistance", Journal of Membran Science, vol. 326, no. 2, pp. 659666, 2009.

[7] Y. Wei, H.-q. Chu, B.-z. Dong, X. Li, S.-j. Sia and Z.-m. Qiiang, "Effect of $\mathrm{TiO}_{2}$ nanowire addition on PVDF ultrafiltration membrane performance", Desalination, vol. 272, no. 1-3, pp. 90-97, 2011.

[8] C. Dong, G. He, H. Li, R. Zhao, Y. Han and Y. Deng, "Antifouling enhancement of poly (vinylidene fluoride) microfiltration membrane by adding $\mathrm{Mg}(\mathrm{OH}) 2$ nanoparticles", Journal of Membrane Science, vol. 387-388, pp. 40-47, 2012.

[9] S. Liang, K. Xiao, Y. Mo and X. Huang, "A novel $\mathrm{ZnO}$ nanoparticle blended polyvinylidene fluoride membrane for antiirreversible fouling", Journal of Membrane Science, vol. 394-395, pp. 184-192, 2012.

[10] X. Wang, Y. Li, X. Lu, W. Zhao and L. Wang, "Fabrication and Characterization of Novel Polyvinyliden Fluoride ultrafiltration mmebranes for separation of $\mathrm{Cr}(\mathrm{VI})$ from wastewater", Adsorption Science and Technology, vol. 34, no. 9-10, pp. 526-537, 2016.

[11] Z. Xu, J. Zhang, M. Shan, Y. Li, B. Li, J. Niu, B. Zhou and X. Qian, "Organosilanefungsionalized graphene oxide for enhanced 
antifouling anda mechanical propperties of polyvinylidene fluoride ultrafiltration membranes", Journal of Membrane Science, vol. 458, pp. 1-13, 2014.

[12] Y. Yuan and T. R. Lee, "Contact Angle and Wetting Properties", Surface Science Techniques, vol. 51, pp. 3-34, 2013.

[13] Margiyani, T. M. S. Basukiwar, M. Kusumawati, and Nita, "Pengaruh komposisi larutan cetak (PVDF/NMP/PEG) dan non pelarut $\left(\mathrm{H}_{2} \mathrm{O} / \mathrm{CH}_{3} \mathrm{OH}\right)$ terhadap kerja membran PVDF dalam pemisalah pewarna indigo", UNESA Journal of Chemistry, vol. 3, no. 3, pp. 170-177, 2014.

[14] S. Zemansky, Fisika untuk Universitas I: Mekanika, Panas dan Bunyi, Bandung: Binacipta, 1994.
[15] P. Bormans, Ceramics are more than Clay Alone, Cambridge: Cambridge International Science Publishing, 2004.

[16] M. P. Fewell, "The atomic nuclide with the highest mean binding energy," American Journal of Physics, vol. 63, no. 7, pp. 653658, 1995.

[17] M. Mulder, Basic Principle of Membrane Technology, Netherlands: SpringnerSciences+Business Media, 1992.

[18] X. Zhao and C. Liu, "One-step fabricated bionuc PVDF ultrafiltration membranes exhibiting innovative antifouling ability to the cake fouling", Journal of Membrane Science, vol. 515, pp. 29-35, 2016. 